\title{
Penguatan Lembaga Adat Tuha Peut Dalam Penyelesaian Sengketa Di Kecamatan Sawang
}

\author{
Yulia, Faisal, Fauzah Nur Aksa \\ Fakultas Hukum Universitas Malikussaleh, Jalan Jawa, Kampus Bukit Indah, Blang Pulo, \\ Muara Dua, Lhokseumawe, Aceh
}

E-mail: yulia@unimal.ac.id

\begin{abstract}
Abstrak - Sosialisasi dan penyuluhan hukum tentang Lembaga Adat Tuha Peut dalam penyelesaian sengketa di Kecamatan Sawang merupakan bagian dari kegiatan pengabdian kepada masyarakat. Latar belakang kegiatan ini adalah dalam Qanun Lembaga Adat, Tuha Peut merupakan salah satu lembaga adat yang berwenang dalam penyelesaian sengketa antar anggota masyarakat suatu gampong (desa). Di Kecamatan Sawang Kabupaten Aceh Utara, masih banyak terdapat sengketa-sengketa adat yang tidak selesai dalam penyelesaian secara adat di gampong dan banyak yang dilaporkan masyarakat ke polisi. Hal ini juga disebabkan kurangnya pengetahuan Lembaga Adat Tuha Peut dalam penyelesaian sengketa pada tingkat gampong. Sosialisasi dan penyuluhan hukum ini dilakukan dengan pemaparan materi dan dilanjutkan diskusi tanya jawab serta umpat balik. Hasil sosialisasi dan penyuluhan hukum di Kecamatan Sawang mendapati bahwa hasil dari umpan balik yang diberikan oleh peserta mengalami peningkatan pemahaman terhadap peran Lembaga Adat Tuha Peut dalam penyelesaian sengketa. Pelaksanaan kegiatan ini mendapat sambutan baik dari Lembaga Adat Tuha Peut, karena mereka sangat jarang mendapatkan pembekalan seperti ini.
\end{abstract}

Kata Kunci — lembaga adat, tuha peut, sengketa, gampong

\begin{abstract}
Socialization and legal counseling on the Tuha Peut Traditional Institution in dispute resolution in Sawang District are part of community service activities. The background of this activity is that in the Qanun of Customary Institutions, Tuha Peut is one of the customary institutions that has the authority to settle disputes between members of a community of a village. In Sawang Subdistrict, Aceh Utara District, there are still many customary disputes that have not been resolved by customary settlement in the village and many have been reported by the community to the police. This is also due to the lack of knowledge of the Tuha Peut Customary Institution in resolving disputes at the village level. This socialization and legal counseling was carried out by presenting the material and continued with a discussion of questions and answers and swearing back. The results of socialization and legal counseling in Sawang District found that the results of the feedback provided by participants experienced an increase in understanding of the role of the Tuha Peut Traditional Institution in dispute resolution. The implementation of this activity received a good response from the Tuha Peut Customary Institution, because they increased their knowledge and they rarely got activities like this.
\end{abstract}

Keywords — customary institution, tuha peut, dispute, village

\section{PENDAHULUAN}

Penyelesaian sengketa dalam masyarakat Hukum Adat secara musyawarah dan mufakat melalui lembaga adat seperti peradilan adat gampong sudah sering dilakukan. Hakim peradilan adat mempunyai wewenang bukan hanya dalam hal perdamaian saja, tetapi juga wenang memutus sengketa dalam setiap penyelesaian sengketa yang mengandung ancaman dan sanksi [1].

Pola penyelesaian sengketa dalam masyarakat adat Aceh dikenal dengan pola penyelesaian secara adat melalui peradilan adat gampong. Pola penyelesaian sengketa dalam masyarakat adat Aceh didasari nilai-nilai Islam yang dicerminkan dalam perilaku kehidupan masyarakat sehari-hari. Adapun tahapan-tahapan dalam penyelesaian sengketa yaitu melalui tahapan pelaporan pokok sengketa, penerimaan laporan oleh aparatur gampong, tahapan persidangan dan terakhir yaitu tahapan pembacaan putusan dan pemberian sanksi kepada pelaku dengan mengedepankan konsep musyawarah demi mewujudkan rasa kedamaian, nilai-nilai kebersamaan dalam masyarakat secara lahir dan bathin [2].

Prinsip kekeluargaan merupakan hal yang terdepan dalam musyawarah bagi masyarakat Aceh, termasuk dalam menjalankan peradilan adat gampong di Aceh. Dalam setiap persoalan dalam masyarakat Aceh, selalu didahulukan penyelesaiannya dengan cara kekeluargaan. Dalam prinsipnya mengedepakan rasa keiklasan masing-masing pihak yang bersengketa. Penyelesaian sengketa secara damai merupakan perbuatan baik dan mulia dalam kebersamaan hidup masyarakat dan hal tersebut merupakan anjuran dalam Hukum Adat [3]. 
Kehidupan adat istiadat dan hukum adat dalam masyarakat Aceh ditegaskan dalam Undang-Undang Nomor 11 Tahun 2006 tentang Pemerintahan Aceh (UUPA), yaitu dalam Pasal 98 UUPA yang mengatur tugas, wewenang, hak dan kewajiban dalam melaksanakan pembinaan kehidupan adat dan adat istiadat dengan membentuk suatu Qanun Aceh. Kemudian diturunkan dalam Qanun Nomor 9 Tahun 2008 tentang Kehidupan Adat dan Adat Istiadat, juga Qanun Nomor 10 Tahun 2008 tentang Lembaga Adat sebagai kearifan lokal masyarakat Aceh dalam menyelenggarakan kehidupan adat [4].

Tuha Peut merupakan salah satu lembaga adat yang berwenang dalam penyelesaian sengketa antar anggota masyarakat suatu gampong di dalam Qanun Lembaga Adat[5]. Unsur-unsur dalam Lembaga Adat Tuha Peut ini yaitu terdiri dari 4 (empat) unsur, yaitu: tokoh ulama, tokoh adat, pemuka masyarakat dan cerdik cendikiawan. Berikut adalah susunan peradilan adat pada tingkat desa di Aceh.

PERADILAN ADAT TINGKAT GAMPONG

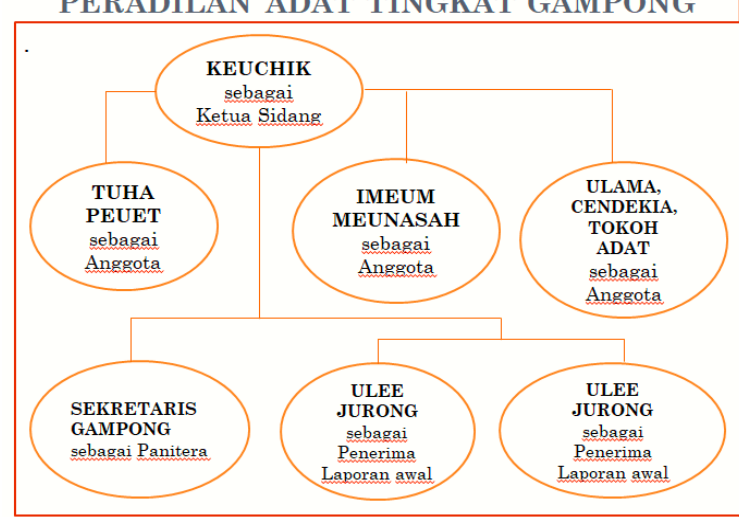

Gambar 1. Susunan pelaksanaan peradilan adat berdasarkan pedoman Majelis Adat Aceh.

Di Kecamatan Sawang Kabupaten Aceh Utara, masih banyak terdapat sengketa-sengketa adat yang tidak selesai dalam penyelesaian secara adat di gampong. Ada juga sengketa yang sudah diputuskan pada tingkat gampong tidak diindahkan oleh para pihak dalam pelaksanaan putusan peradilan adat. Di samping itu, terdapat sengketa adat yang langsung dilaporkan masyarakat ke polisi di Kepolisian Sektor Sawang. Dengan demikan, ketika Lembaga Adat Tuha Peut tidak atau kurang pengetahuan dalam penyelesaian sengketa akan muncul permasalahan ketidakpercayaan dalam penyelesaian sengketa melalui peradilan adat gampong [6].

Berdasarkan kondisi tersebut, terdapat alasan prinsipil dan penting untuk dilaksanakan sosialisasi dan penyuluhan hukum kepada Lembaga Adat Tuha Peut di Kecamatan Sawang, yaitu dalam upaya memperkuat Lembaga Adat Tuha Peut dalam penyelesaian perselisihan masyarakat. Sosialisasi dan penyuluhan hukum merupakan salah satu langkah strategi untuk menguatkan penyelesaian sengketa melalui peradilan adat gampong [7], termasuk peran Lembaga Adat Tuha Peut dalam penyelesaian sengketa di gampong.

\section{MetOde PELAKSANAAN}

Pelaksanaan pengabdian kepada masyarakat dilakukan dengan menggunakan metode sosialisasi dan penyuluhan hukum kepada Lembaga Adat Tuha Peut yang ada di 4 (empat) gampong dalam Kecamatan Sawang. Gampong yang menjadi lokasi sosialisasi dan penyuluhan hukum tersebut adalah Gampong Blang Teurakan, Gampong Sawang, Gampong Riseh Baroh, dan Gampong Riseh Tengoh.

Sosialisasi dan penyuluhan hukum dilakukan pada masing-masing gampong tersebut dengan menghadirkan perserta yaitu Lembaga Adat Tuha Peut, Imum Menasah, Kepala Desa, Sekretaris Desa dan Kepala Dusun. Waktu pelaksanaan pada Rabu dan Kamis, 25-26 November 2020.

Sosialisasi dan penyuluhan hukum dilakukan oleh Dosen Fakultas Hukum Universitas Malikussaleh sebagai tim pelaksana. Materi sosialisasi dan penyuluhan hukum yang disampaikan berkaitan dengan:

- Keberadaan Qanun Lembaga Adat nomor 10 Tahun 2008

- Fungsi dan wewenang Lembaga Adat Tuha Peut

- Pedoman peradilan Adat

- Jenis-jenis perkara yang diselesaikan pada tingkat peradilan adat Gampong

Sosialisasi dan penyuluhan hukum diawali dengan tes awal sebelum pemaparan materi kemudian dilanjutkan penyampaian materi oleh tim pengabdi yang diikuti dengan diskusi tanya jawab tentang penyelesaian sengketa di tingkat gampong. Para peserta sangat antusias mengajukan pertanyaan pada saat sesi tanya jawab. Kemudian juga dilakukan juga tes setelah penyampaian dilakukan tes sebagai umpan balik untuk mengetahui kemampuan peserta setelah mendapat materi.

\section{HASIL DAN PEMBAHASAN}

Pelaksanaan sosialisasi dan penyuluhan hukum secara keseluruhan meliputi aspek-aspek sebagai berikut: 1. Jumlah peserta sosialisasi dan penyuluhan hukum yang berhasil mencapai target; 2. Ketercapaian tujuan sosialisasi dan penyuluhan hukum; 3 . Ketercapaian target materi yang telah direncanakan; 4 . Para peserta mampu menguasai materi yang disampaikan oleh Tim Pengabdi.

Dalam penyampaian materi dilakukan dengan menayangkan materi melalui infocus dan juga membagikan fotocopi materi sebagai panduan kepada peserta. Proses pemaparan materi dalam pelaksanaan sosialisasi dan penyuluhan hukum tentang Penguatan Lembaga Adat Tuha Peut Dalam Penyelesaian 
Sengketa di Kecamatan Sawang sebagaimana terlihat dalam gambar 2 dan 3 berikut ini:

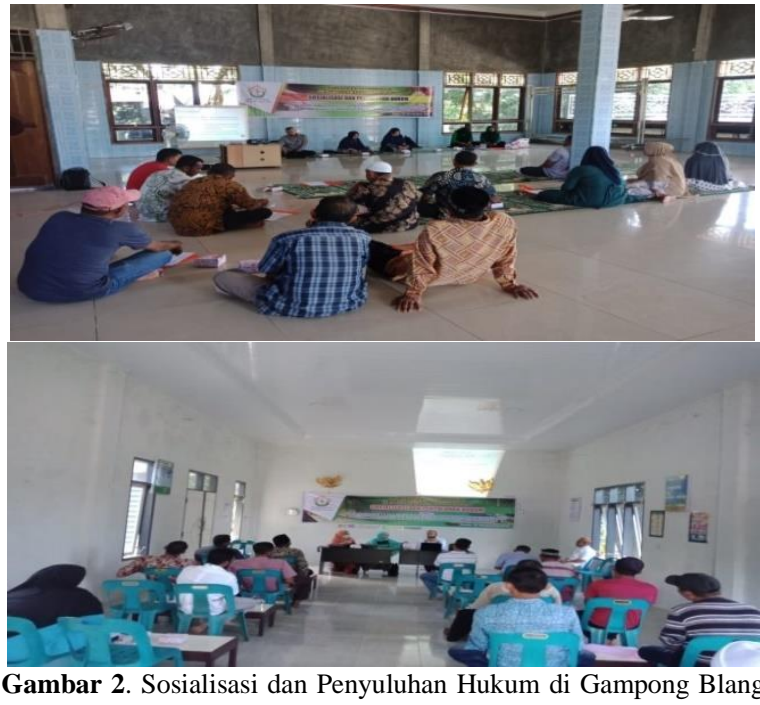

Teurakan dan Keude Sawang, Kecamatan Sawang

Sosialisasi dan penyuluhan hukum diikuti oleh 45 orang peserta dari Gampong Blang Teurakan, Sawang, Riseh Baroh dan Riseh Tengoh. Jumlah peserta yang hadir sudah memenuhi target yang ditetapkan dalam rencana. Peserta memiliki semangat yang tinggi, di mana peserta tidak meninggalkan ruangan sampai akhir penutupan dengan foto bersama sebagaimana diperlihatkan dalam gambar berikut ini:

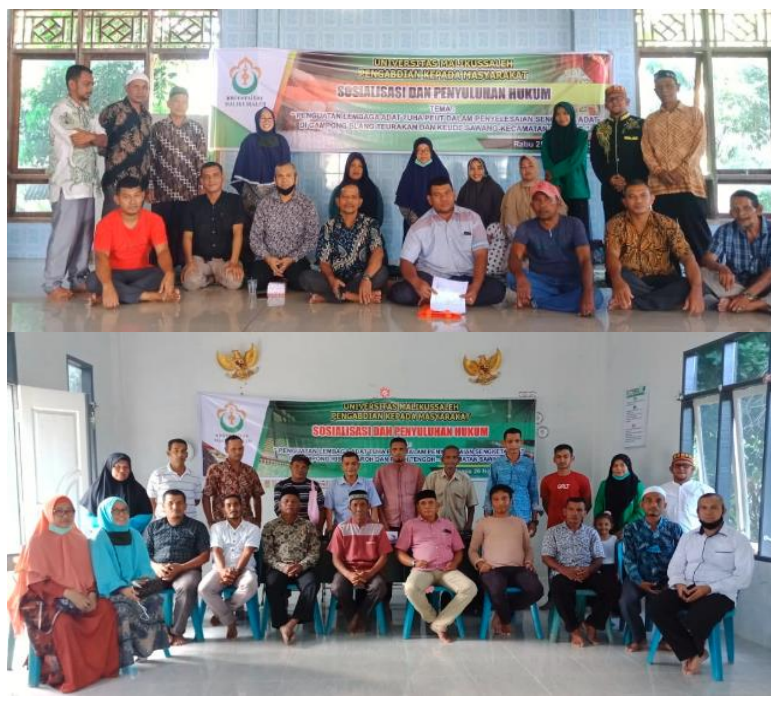

Gambar 3. Foto bersama seusai Sosialisasi dan Penyuluhan Hukum di Gampong Blang Teurakan, Sawang, Riseh Baroh dan Riseh Tengoh, Kecamatan Sawang

Pertanyaan-pertanyaan para peserta, di antaranya adalah:

1. Sengketa apa saja yang diselesaikan di tingkat gampong?

Jawaban pemateri: Dalam Qanun Nomor 9 Tahun 2008 tentang Pembinaan Kehidupan Adat dan
Adat Istiadat, terdapat 18 sengketa yang dapat diselesaikan pada tingkat gampong, yaitu:

a. Perselisihan dalam rumah tangga.

b. Sengketa antara keluarga yang berkaitan dengan faraidh.

c. Perselisihan antar warga.

d. Khalwat (mesum).

e. Perselisihan tentang hak milik.

f. Pencurian dalam keluarga (pencurian ringan)

g. Perselishan harta sehareukat;

h. Pencurian ringan;

i. Pencurian ternak peliharaan;

j. Pelanggaran adat tentang ternak, pertanian dan hutan;

k. Persengketaan di laut;

1. Persengketaan di pasar;

m. Penganiayaan ringan;

n. Pembakaran hutan (dalam skala kecil yang merugikan komunitas adat);

o. Pelecehan, fitnah, hasut dan pencemaran nama baik;

p. Pencemaran ligkungan (skala ringan);

q. Ancaman mengancam (tergantung dari jenis ancaman); dan

r. Perselishan perselisihan lain yang melanggar adat dan adat istiadat.

2. Bagaimanakah jika yang melanggar adalah Lembaga Adat Tuha Peut atau Keuchik (Kepala Desa), siapa yang menyelesaikan?

Jawaban pemateri: dalam penyelesaian sengketa yang dilakukan Lembaga Adat Tuha Peut atau Keuchik, maka yang menyelesaikan adalah Lembaga Adat Imum Mukim. Lembaga Adat tersebut merupakan tingkat penyelesaian sengketa setelah tingkat gampong (Lembaga Adat Imum Mukim mempunyai wilayah yang disebut dengan Mukim yaitu Kesatuan Masyarakat Hukum Adat dalam Propinsi Daerah Istimewa Aceh yang terdiri dari beberapa gampong yang mempunyai batas-batas wilayah tertentu dan harta kekayaan sendiri dalam suatu kecamatan). Dalam melaksanakan persidangan ditingkat mukim, majelis hakim terdiri dari: Imum Mukim (kepala mukim), Imum Chik (Imam Masjid), Tuha Peut Mukim (Dewan Pertimbangan Mukim), Sekretaris Mukim sebagai panitera, serta ulama/pakar.

3. Bagaimanakah, apabila hasil putusan tidak diindahkan oleh para pihak?

Jawaban pemateri: Dalam teknis pelaksanaan penyelesaian sengketa pada tingkat gampong telah diatur dalam Diktum Keenam Surat Keputusan Bersama (SKB) Gubernur Aceh, Kepala Kepolisian Daerah Aceh dan Ketua Majelis Adat Aceh tahun 
2012, secara tegas menyatakan bahwa "putusan Peradilan Adat Gampong bersifat final dan mengikat". Artinya, sengketa tersebut tidak dapat diajukan ke pengadilan atau mahkamah. Kemudian ditegaskan dalam juga dalam Pasal 18 ayat (1) Pergub Aceh 60/2013 bahwa, "Putusan Peradilan Adat bersifat damai dan mengikat". Oleh karena itu, putusan tersebut dapat dilaksanakan dan memiliki kekuatan hukum untuk dilaksanakan. apabila tidak dilaksanakan, lembaga adat dapat melakukan pemaksaan untuk dipatuhi.

Tujuan sosialisasi dan penyuluhan hukum secara keseluruhan sudah tercapai dalam penguasaan materi oleh peserta yang mampu menjawab pertanyaan-pertanyaan dalam post-test yang mencapai skor tinggi pada masing-masing lokasi pelaksanaan dibandingkan dengan hasil sebelum pemaparan materi. Hasil ini sebagaimana diperlihatkan perbandingan hasil pre-test dan post-test dalam tabel 1 dan 2 di bawah ini:

Tabel 1. Hasil tes sebelum pemaparan materi

\begin{tabular}{lccccc}
\hline \multirow{2}{*}{ GAMPONG } & $\begin{array}{c}\text { Jumlah } \\
\text { Peserta }\end{array}$ & \multicolumn{3}{c}{ SKOR NILAI (\%) } \\
\cline { 3 - 6 } & $/ \%$ & $\mathbf{6 5}$ & $\mathbf{8 0}-$ & $\mathbf{8 0 0}-$ \\
\hline Blang & & & & \\
Teurakan $\quad \&$ & 20 & 16 & 3 & 1 \\
Sawang & 100 & $\mathbf{6 4}$ & $\mathbf{1 5}$ & $\mathbf{5}$ \\
\hline Riseh Baroh \& & & & & \\
Riseh Tengoh & 25 & 17 & 8 & 0 \\
& 100 & $\mathbf{6 8}$ & $\mathbf{3 2}$ & $\mathbf{0}$ \\
\hline
\end{tabular}

Tabel 2. Hasil tes setelah pemaparan materi

\begin{tabular}{|c|c|c|c|c|}
\hline \multirow[b]{2}{*}{ GAMPONG } & \multirow[b]{2}{*}{$\begin{array}{c}\text { Jumlah } \\
\text { Perserta }\end{array}$} & \multicolumn{3}{|c|}{ SKOR NILAI (\%) } \\
\hline & & $\leq 65$ & $\geq 66-80$ & $\begin{array}{c}\geq 90- \\
100\end{array}$ \\
\hline Blang & & & & \\
\hline Teurakan \& & 20 & 2 & 5 & 13 \\
\hline Sawang & 100 & 10 & 25 & 65 \\
\hline Riseh Baroh & & & & \\
\hline \& $\quad$ Riseh & 25 & 1 & 6 & 18 \\
\hline Tengoh & 100 & 4 & 24 & 72 \\
\hline
\end{tabular}

Skor nilai sebelum pemaparan materi yang diperlihatkan tabel 1, lebih kecil sama dengan 65 mencapai $64 \%$ dan $68 \%$. Sedangkan hasil tes setelah pemaparan materi di dalam tabel 2, skor nilai di atas 90 mencapai $65 \%$ dan $72 \%$. Oleh karena itu, adanya peningkatan skor nilai yang disebabkan peningkatan kemampuan pemahaman peserta terhadap materi yang disampaikan oleh pemateri. Secara umum pemahaman peserta terhadap materi sebelum dan sesudah pemaparan materi sebagaimana diperlihatkan dalam tabel 3 di bawah ini:
Tabel 3. Lembaga Adat Tuha Peut sebelum dan sesudah sosialisasi dan penyuluhan hukum

\begin{tabular}{ll}
\multicolumn{1}{c}{$\begin{array}{c}\text { Sebelum sosialisasi dan } \\
\text { penyuluhan hukum }\end{array}$} & \multicolumn{1}{c}{$\begin{array}{c}\text { Setelah sosialisasi dan } \\
\text { penyuluhan hukum }\end{array}$} \\
\hline $\begin{array}{l}\text { Lembaga Adat Tuha Peut belum } \\
\text { mengetahui tentang Qanun } \\
\text { Lembaga Adat }\end{array}$ & $\begin{array}{l}\text { Lembaga Adat Tuha Peut sudah } \\
\text { mengetahui tentang Qanun } \\
\text { Lembaga Adat. }\end{array}$ \\
$\begin{array}{l}\text { Lembaga Adat Tuha Peut belum } \\
\text { mengetahui pedoman } \\
\text { penyelesaian sengketa melalui } \\
\text { peradilan adat. }\end{array}$ & $\begin{array}{l}\text { Lembaga Adat Tuha Peut sudah } \\
\text { mengetahui pedoman } \\
\text { penyelesaian sengketa melalui } \\
\text { peradilan adat. }\end{array}$ \\
$\begin{array}{l}\text { Lembaga Adat Tuha Peut belum } \\
\text { mengetahui filosofis } \\
\text { penyelesaian sengketa melalui } \\
\text { peradilan adat. }\end{array}$ & $\begin{array}{l}\text { Lembaga Adat Tuha Peut sudah } \\
\text { mengetahui filosofis } \\
\text { penyelesaian sengketa melalui } \\
\text { peradilan adat. }\end{array}$ \\
$\begin{array}{l}\text { Lembaga Adat Tuha Peut tidak } \\
\text { mengetahui fungsi masing- } \\
\text { masing anggota tuha peut dalam } \\
\text { penyelesaian sengketa melalui } \\
\text { peradilan adat. }\end{array}$ & $\begin{array}{l}\text { Lembaga Adat Tuha Peut } \\
\text { mengetahui fungsi masing- } \\
\text { masing anggota tuha peut } \\
\text { dalam penyelesaian sengketa } \\
\text { melalui peradilan adat. }\end{array}$ \\
\hline
\end{tabular}

Berdasarkan hasil kegiatan dalam tabel 3 di atas, menunjukkan pelaksanaan sosialisasi dan penyuluhan hukum sudah dapat meningkatkan pengetahuan Lembaga Adat Tuha Peut dalam penyelesaian sengketa. Hasil umpat balik juga berguna sebagai acuan dalam pengembangan program pengabdian kepada masyarakat berkaitan dengan lembaga adat pada periode berikutnya.

\section{KESIMPULAN}

Sosialisasi dan penyuluhan hukum sebagai salah satu metode dalam pengabdian kepada masyarakat sudah berhasil mencapai tujuan. Para peserta sangat antusias dan aktif mengikuti sosialisasi dan penyuluhan hukum. Rekomendasi kepada Lembaga Penelitian dan Pengabdian kepada Masyarakat Universitas Malikussaleh perlu terus menerus mendukung dilakukannya sosialisasi dan penyuluhan hukum agar segala bentuk informasi hukum tersampaikan kepada masyarakat, khususnya lokasi-lokasi yang masih jarang tersentuh dengan informasi hukum secara langsung.

\section{UCAPAN TERIMA KASIH}

Ucapan terima kasih dari Tim Pengabdian kepada Lembaga Penelitian dan Pengabdian kepada Masyarakat Universitas Malikussaleh yang telah memfasilitasi pelaksanaan Pengabdian kepada Masyarakat tahun 2020, semoga kegiatan ini dapat meningkatkan kinerja dosen dan lembaga. 


\section{DAFTAR PUSTAKA}

[1] Asnawi Zainun, 2018. Kedudukan Fungsi Dan Peran Lembaga Adat Di Aceh (Kajian Qanun Aceh Nomor 10 Tahun 2008 Tentang Lembaga Adat, Buletin Balee Mukim.

[2] Muhammad Iqbal, et al. 2020. Pola Penyelesaian Sengketa Dalam Rumah Tangga Jurnal Geuthèè: Penelitian Multidisiplin Melalui Peradilan Adat Gampong Di Aceh Vol. 03, No. 01, 383-392.

[3] Taqwaddin Husin, 2015. Penyelesaian Sengketa/Perselisihan Secara Adat Gampong Di Aceh Customary Dispute Settlement In Aceh, Kanun Jurnal Ilmu Hukum No. 67, Th. XVII, 511-532.

[4] Apri Rotin Djusfi, 2018. Keberadaan Tuha Peut Gampong Dalam Penyelesaian perselisihan
Hukum Adat Aceh, Jurnal Public Policy, Vol 2, No 1, 51-58.

[5] Teuku Saiful, 2020. Peran Perangkat Adat Desadalam Penyelesaian Sengketa Melalui Pendekatan Hukum Peradilan Adat Di Aceh, Jurnal Hukum Doktrinal, vol 2 No 2.

[6] Delfi Suganda, 2018. Fungsi Strategis Tuha Peut Dalam Melakukan Pengawasan Dan Pencegahan Korupsi Dana Gampong, Al-Idarah: Jurnal Manajemen Dan Administrasi Islam, Vol. 2, No. 1, 61-74.

[7] Juniarti, 2012. Peran Strategis Peradilan Adat Di Aceh Dalam Memberikan Keadilan Bagi Perempuan Dan Kaum Marjinal, Prosising Konferensi AICIS XII, UIN Arraniry, Banda Aceh. 
